\title{
USE OF PROJECT MANAGEMENT IN CREATING AND DEVELOPING A START-UP
}

\begin{abstract}
This article's purpose is to present the assumptions underlying an integrated, agile-line approach to management of a start-up project and to propose a model for the management of such an innovative project. In addition to the theory related to project management and start-ups, this article discusses existing project management methods and their uses and compares them with typical needs of start-ups. To analyse the above-mentioned goal and yield reliable research results, a qualitative method was used, i.e., interviews with specialists and practitioners from the project management and start-up industries. As a result of the research, a model is proposed, including its phases and documents and tools necessary to each phase. Future research should be developed in a practical direction, i.e., it should be based on failed start-ups.
\end{abstract}

Keywords: project management, start-up, management, methodology project management.

\section{INTRODUCTION}

Globalisation, innovation and technological change play a key role in shaping the current labour market model (Balcerowicz-Szkutnik, Sroka, 2020). As a result, the market is a constant change, and each company meet new threats and opportunities. Changes create new needs and direct the company to define the objectives necessary to achieve a competitive advantage. The whole process of action and the way to reach the desired state is called a project (Małyszek, 2020). Projects can have a variety of forms, once they were only of a constructional and technical nature but nowadays they occur in all areas of human activity. The development of projects in all areas of activity was forced by changes in the functioning of the organization and an increase in information resources (Szmigiel, Strojny, 2015). The project can also be an innovative process, which the company creates to build a new image or a product (Wijmans, 2021). Along with the emerging need for dynamic changes, there was also a need to learn how to manage innovative projects, which it is necessary to combine to develop a model suitable for a given company and project. The literature lacks the use of both agile and linear methods at the same time. Innovation is any improvement of the current state or creation of a new product/service. An innovation has a key role, but not every change can be considered as an innovation. It is primarily to create a solution or introduce a change that is necessary and practical (Bukowski, Szpor, 2012).

\footnotetext{
${ }^{1}$ Agata Wojciechowska, MSc, Department of Project Management and Security Policy, Faculty of Management, The Rzeszów University of Technology, 10 Powstańców Warszawy Ave., 35-959 Rzeszów; e-mail: a.wojciecho1@ @rz.edu.pl. ORCID: 0000-0001-7075-2767.
} 
Along with the concept of innovation, comes the concept of start-up, which is defined as a temporary organization looking for a viable and scalable business model (Blank, 2013). There is no clear action path for a start-up, and we don't know when it becomes a company, but it is certain that a start-up is the initial stage of a project (Blank, 2012). Moreover, in recent years it has also developed as a scientific discipline (Berkun, 2006). Adaptation to change is a key element in the activities of current companies and organizations, while project management allows to manage change.

The purpose of the article is to present the assumptions of an integrated agile-line approach to the management of a start-up project, to indicate the possibilities, project specifications and to present a proposed model of innovative project management, which has been verified and refined on the basis of expert interviews. A research problem that will be explained is: How to manage a startup project? There is no clearly defined way in the literature on how to start a project and manage it with project management. In this article, the authors try to present many methods and types of related solutions so that the reader can easily and consciously combine them with each other and decide for himself which method will be most beneficial for the type of organization he knows or will be able to act. Understanding the needs of the organization provides many opportunities and allows it to become competitive.

Start-up is a process of continuous learning and experimentation, and the very cycle of management of a start-up project requires continuous verification of ideas and consists of the following phases (Brzeziński, 2009): discovery, precision of ideas, business justification, product/service development, testing and market. R. A. Baron and R. A. Henry indicate the stages of the entrepreneurial process, emphasizing in the first stage creative thinking and high risk, the second stage belongs to people who are communicative, able to build a portfolio of clients and survive and stay in the market in crisis and the last stage, which is the transition to a mature company (Baron, Henry, 2011). These processes are similar to each other and have almost identical steps. Regardless of the approach, this is a project that will not always be successful (Kubera, 2016).

Innovative designs should be repeatedly tested to ensure that the problem existing in the market is solved and adapted to the changes required by the aftermarket customer (Clarke, 1997). A product or service created in an innovative process should be effective, easy to use, reliable, flexible and meet the emotional expectations of the customer (Engle, 2013). Expectations can be met when we perform tests and collect feedback from potential customers (Chandrashekar, Mungila Hillemane, Satyanarayana, 2013).

People who start a business, have the opportunity to take advantage of many funding opportunities to exclude financial failure, can take advantage of the power of the Business Angel. Such a person helps to commercialise or financially support a product/service (Arundale, 2007). Start-up is an innovative activity, but the authors of books and articles present only the successes of large companies, forgetting about the very process of creating and managing a start-up. (Start-up Latin America 2016: building an innovative future, 2016).

It is difficult for scientists to define innovation, it results from the development of the market or dynamic changes, while the most important aspect was quoted by Z. Orbik, pointing to the most important aspect that hinders the definition of innovation, i.e. taking into account new phenomena, objects and processes. (Orbik, 2017). 
For this reason, the authors begin to explore the concept of innovation and combine it with project management. Currently, the innovative process of innovation is defined as activities necessary to develop modern and practical solutions (Wziątek-Kubiak, 2011).

\section{TYPES OF PROJECT MANAGEMENT METHODOLOGIES}

A project is defined a goal-oriented process and its achievement is either a success or a failure (Maduss, 2006). Project management was created in response to the needs of innovative ventures when traditional methods proved insufficient (Pawlak, 2006). Project management is a universal methodology that can be used in organizations with different characteristics, e.g. National Aeronautics Space Administration). Traditional project management methodologies are called linear/cascade and are based on the project life cycle and sequential actions, they work well in situations where the purpose and technique of action are clearly defined and there is little probability of changes (Szmigiel, Strojny, 2015). They do not allow for the possibility of significant changes during the project.

The search for methods adapted to projects characterized by variability began. In response to this need, agile project management methodologies have been used. In addition to innovation and variability, they are characterized by shortening the time of product delivery and adapting to a turbulent environment (Wirkus, Zejer, 2017).

In the traditional approach we can distinguish: PMI, PRINCE2 and IPMA. Whereas in the agile approach: SCRUM, KANBAN and LEAN. Figure 1 shows the division of approaches to project management.

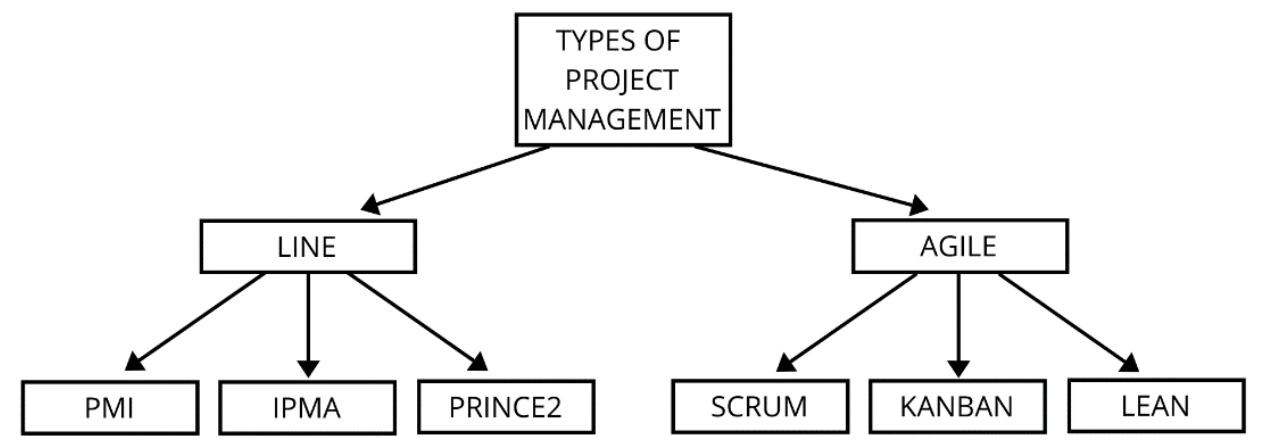

Figure 1. Types of project management

Source: own study.

PMI's methodology is a set of rules and standards for project management, which has been defined and arranged in the publication A Guide to the Project Management Body from Knowledge (PMBOK ${ }^{\circledR}$ Guide) (Wirkus, Zejer, 2014). PMI gives the possibility to characterize many processes and dependencies and gives the possibility to choose the necessary from among 42 presented e.g. monitoring, initiation or planning processes (Project Management Institute, 2008).

International Project Management Association is an organization that focuses on the activities of a manager, his or her competences and sets standards for three areas: project, program and portfolio, which are divided into three areas (perspective, people and practice). 
PRINCE2 as the third of the linear methodologies that contains four main elements: principles, themes, processes and project environment, based on principles such as continuous business case studies, use of experience, defined roles and responsibility tools, step-by-step management or product orientation. It sets out guidelines on how to verify the project in terms of business relevance. PRINCE 2, on the other hand, precisely defines the organizational structure and the lack of flexibility of adjustment to a given organization (Wirkus, 2014).

The agile methodology, which is SCRUM, is characterized by orientation towards the project's stakeholders, providing functionalities that are specified at the time of subsequent iterations of the project with the client, and the schedule consists of short value creation processes. This method allows for flexible organization of work in order to react quickly to changes (Szmigiel, Strojny, 2015). SCRUM specifies the role in the project and imposes participation in frequent team meetings, which are called sprints. The KANBAN approach is also agile and bases its actions on visualization of the whole process, through KANBAN tables, dividing tasks into: to do, in progress, tests, completed tasks. The approach is also associated with the "no chair" meeting method and retrospection, which help to better understand the mistakes and improve the project (.system-kanban.pl,2020). The advantages of agile methods are also the transparency of the project, short, clearly defined tasks, and no waste and delivery of the product/service actually needed by the customer. In addition to the disadvantages, there is the need for constant supervision and control and the involvement of all employees.

Start-up is an innovative project, without developed schemes, so they are necessary to work out, in such a way as to meet the actual needs of the customer, a ready-made scheme can be applied, but it may lead to delays and a significant slowdown in the implementation process, due to a different specificity of the project (Chmielarz, 2012). The complete lack of a schedule may lead to the idea's collapse and its completion, therefore it is necessary to introduce work planning regardless of the methodology chosen.

\section{RESEARCH METHODOLOGY}

The purpose of the article is to present the assumptions of an integrated agile-line approach to the management of a start-up project, to indicate the possibilities, project specifications and to present a proposed model of innovative project management. Defining the purpose of the article allows the author to specify the direction of research and the research problem, i.e. the state of ignorance of an objective nature (Apanowicz, 2002). The research problem that will be explained is: How to manage a start-up project? The research was carried out by means of an expert interview, which is a qualitative method and allows to know the exact approach of practitioners and their way of thinking (Stemplewska-Żakowicz, 2010). The research problem will be specified through the following detailed research questions:

1. What elements of the project management methodology can be used to manage a start-up project?

2. What techniques support the preparation and implementation of a start-up project?

3. What documents support the preparation and implementation of a start-up project?

The participants of the expert interview were specialists and professionals in the field of project management and start-ups. These practitioners have dealt with the issues of project 
management, start-ups, and innovation on a daily basis and cooperate with many companies throughout Poland. The expert interviews were conducted with three specialists:

- Jacek Strojny,

- Bartosz Jadam,

- Marcin Drozd.

Jacek Strojny is a specialist in project management, the second person, Bartosz Jadam, who closely cooperates with start-ups and knows its specifics, and the third specialist, Marcin Drozd, who founded a start-up and knows its specifics very well. The questionnaire consisted of 9 open ended questions. The interviews were conducted using the semistructured interview method, which addressed many aspects related to project management and start-ups:

- the concept of start-up, the concept of project management and understanding of project management in start-up,

- ideal phases of an innovative project,

- documents necessary in particular phases of the start-up project,

- avoiding waste in innovative undertakings,

- the project start-up will turn into a process-proven company,

- the most desirable competence/skills of a manager, including a start-up, project manager, company owner,

- desired competence and skills of project team members,

- the possibility of carrying out a start-up project through the cascade model phases,

- the need for innovation on the market.

The interview allowed for exploring the topics and getting to know the project management process, the process of creating / creating a start-up as well as verifying the management model proposed by the author and refining it based on the practical knowledge of experts. This knowledge is of key importance due to the fact that the concept of a startup is not precisely defined in science. The concept is young and everyone interprets it in their own way, therefore many aspects on which further research can be based are missing. Start-up is defined as an innovative project, characterized by a lack of linearity, which allows to combine research with the concept of project management (Sońta-Drączkowska, 2018). The life cycle of a start-up is specific because it combines existing processes, implemented and used in companies with non-existent or emerging ones (Kałowski, Wysocki, 2017). The expert interview led to the development of the necessary elements of the management process for an ideal agile-line model for managing a start-up project.

\section{RESEARCH RESULTS}

The first questions was about the definition of a start-up, project management and project management in start-up. The terms are understood differently by each of the specialists, start-up by Jacek Strojny is considered to be a project in which one can base less on the knowledge gained so far, and project management is leading from the idea to the creation of the final product. Whereas project management in a start-up is managing uncertainty and discovering what innovation is supposed to consist in, you cannot run a project linearly, but agilely, which translates into selected methods and techniques. The second specialist, Bartosz Jadam, understands project management as information management and a place to make mistakes, while a start-up is any undertaking that does not have repetitive solutions. This specialist thinks that project management in a start-up is 
a clue that has to be adjusted to the specificity of the project. The third specialist described a start-up as an IT or Fine-tech company that is focused on the effect of scale in a very short period of time with a degree of innovation. He specified project management as a tool to help run the company and linked project management in a start-up with the concept of "kaizen", i.e. improvement of all possible aspects of the business and an innovative approach to company management.

The second question was about defining the stages in a start-up project. Each of them pointed out that it is not the name that matters, but the activities contained in them and the use of agile instead of linear methodologies. The first specialist defined three phases, following the standard phase model, the initial phase/idea then the transition to a phase of clarification and implementation, which are ongoing at the same time and the transition to a phase of closure of the start-up, in which the business moves on to repetitive processes and schemes of activities. The start-up specialist has defined the phases in a similar way, but has included specific actions in them. The first phase is also an idea/initiative in which iteration, market research, definition of the value to be delivered to the customer occurs. He defined the next phase as value identification, including identifying needs and trying out a tool for a problem that may occur during implementation. This phase determines the transition to the next related product identification, including the creation of methods and procedures to reach the customer, the phase of making mistakes, looking for ideal solutions and making key decisions. During the value identification phase and product identification there are several iterations, until the product value is specified. The last phase that Bartosz Jadam has defined is product implementation and market entry. The third specialist on the basis of a start-up created by him briefly defined three phases. The first one is to check the market and the parameters we want to provide, then to determine the recipients and possibilities of technology implementation, as the last phase he defined fundraising. He emphasized the fact of providing solutions at cost on an ongoing basis to test the product with the customer.

Another of the questions concerned documents necessary in particular phases of the start-up project. All specialists unanimously determined that the most important document is the one in which the saved ideas will be saved, e.g. in the form of Google Disc. The database with your own ideas should be created together with each project, additionally Jacek Strojny described transferring analyses and ideas to schemes as necessary imaging to find the missing elements. For Bartosz Jadam the issue of product description is very important, if the creator is not able to include the description of the idea on one page, he will probably never be able to sell the product. Legal documents concerning intellectual property are also important to protect the start-up from both internal and external risks, additionally Jacek Strojny believes that the ideal document would be a project card that would allow to prepare the start-up in different ways of financing, which would avoid lack of financing, because in the case of EU grants the tranches of the loan must be clarified according to the schedule, and e.g. Business Angels do not need a linear approach, but the very description of the idea and sale is necessary. Additionally, Marcin Drozd drew attention to the necessity of the changes and bad decisions in the project in order not to repeat the mistakes that have already occurred. Documentation is necessary in the project according to all specialists, everyone has defined different documents, but unanimously believe that it is not possible to specify in which phase which document should be in. It all depends on the specifics of the project and the matching of specific phases to the start-up. 
The next elements was the avoiding waste in innovative undertakings. Creating the above mentioned documents during a start-up project helps to avoid wastage, thanks to that:

- determining the risk and its dimension,

- using other people's experience,

- understanding the market/competition and the needs of potential customers,

- not to follow "blindly" the goal set at the beginning of the project,

- focusing on the essential elements of the project.

Start-up is a project that should be relatively fast until completion, but it is very difficult to determine the exact framework when such a moment occurs. Bartosz Jadam specified that a start-up stops being a start-up when it stops "pivoting", the target market is defined, sales and changes start being made based on external clients. When entering the phase of introducing modifications in the project understanding, the start-up becomes a company. On the other hand, Jacek Strojny described the transition from a start-up to a company in a slightly different way, as a transition to the established schemes and use of standardized solutions and processes. Repeatable schemes include product sales, marketing, product manufacturing process. A completely different approach was presented by Marcin Drozd, according to which at the beginning a company is created and then it goes into a start-up, because every activity must be a company from the legal point of view, it should be registered. The company is transformed into a start-up at the moment when the activity reaches the effect of scale.

At the end, the issues of the desired competences of a project manager, cascading a start-up and the need to implement innovations were discussed. All experts agreed on the project team and its inter-disciplinarity and the selection of people for the team depending on its specificity. The most important features mentioned were communicativeness, determination, creativity and organization. The experts approved the fact that a start-up can be managed through a standard cascade model, i.e. initiation, planning, implementation, completion, but it needs to be modified accordingly, e.g. by combining the planning and implementation phase. The last stage of the interview raised the issue of the importance of innovation among the entities currently operating on the market. Innovation is not necessary for functioning on the market, but proactivity is equally important.

\section{SUMMARY}

Innovative project should develop by working on errors, phases in the start-up project should be adjusted to its specificity, the most important thing is to iterate with the prototype many times during the start-up and acquire skills. The first phase is the idea itself and its definition, the next phase is iteration, learning and multiple tests with the product/service recipient. The third phase should include the finalisation, i.e. it is the stage when the final product is released for sale in the process. The proposed structure of the phases of an innovative project is presented in the following figure 2.

The proposed phases of an innovative project are similar to those already existing in the literature, e.g. M. Rogers' model consists of six phases presented in Figure 3, including: need / problem, research, development, commercialization, diffusion and the consequences of adopting an innovation. Rogers emphasizes that the phases, depending on the needs, may occur in a different order (Beausoleil, 2018). The innovative project management model proposed in the article contains a significant difference - the deeming cycle, i.e. the process of continuous learning. This approach is based on agile management and the design thinking 
approach and consists in working on the product in such a way as to satisfy the user, not only at the end of the project, but at every stage of it, and delivering visible work progress. The iterative approach is used in scrum and combined with the standards of cascading project management methodologies, i.e. clearly defined stages, allows to maximize the benefits of the project.

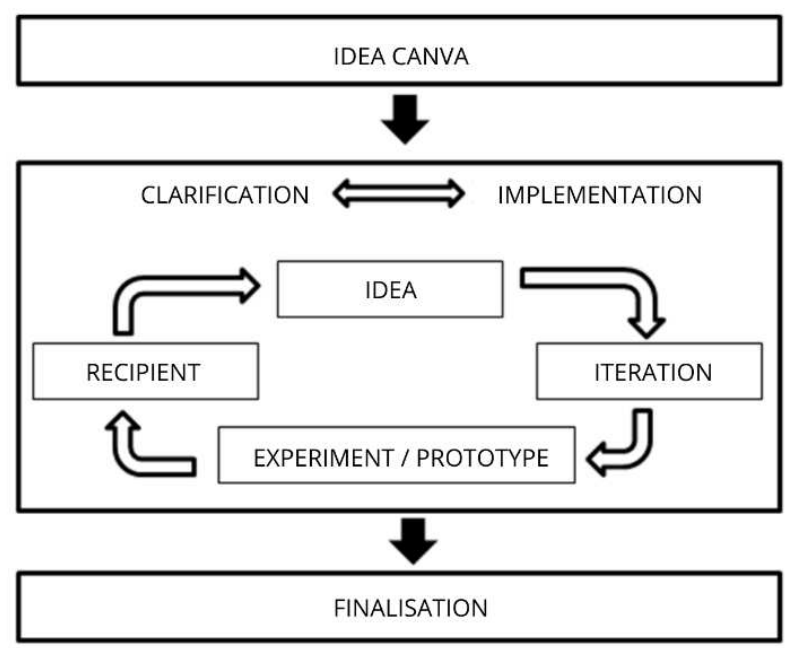

Figure 2. Proposed phases of an innovative project

Source: own study.

\begin{tabular}{|c|c|c|c|c|c|}
\hline $\begin{array}{ll}\text { INITIATION } & \text { Info } \\
\text { con }\end{array}$ & $\begin{array}{l}\text { tion gathering, } \\
\text { ualizing and planning. }\end{array}$ & DECISION & IMPLEMENTATION & $\begin{array}{l}\text { All events, actions, decisions i } \\
\text { innovation into use. }\end{array}$ & Ived with putting an \\
\hline $\begin{array}{l}\text { 1. NEEDS/ } \\
\text { PROBLEMS }\end{array}$ & 2. RESEARCH & 3. DEVELOPMENT & $\begin{array}{l}\text { 4. COMMERCIAL- } \\
\text { IZATION }\end{array}$ & $\begin{array}{l}\text { 5. DIFFUSION } \\
\text { AND ADOPTION }\end{array}$ & 6. CONSEQUENCES \\
\hline $\begin{array}{l}\text { Inquiry into the lack } \\
\text { of innovation } \\
\text { process and } \\
\text { innovative } \\
\text { competencies } \\
\text { understanding; } \\
\text { reduce uncertainty } \\
\text { with process. }\end{array}$ & $\begin{array}{l}\text { Investigation of } \\
\text { academicand } \\
\text { industry } \\
\text { frameworks, and } \\
\text { models of } \\
\text { normative } \\
\text { innovation } \\
\text { processes. }\end{array}$ & $\begin{array}{l}\text { Prototyping and } \\
\text { proposing a } \\
\text { normative } \\
\text { frameworkfor } \\
\text { action-research } \\
\text { study with } \\
\text { potential } \\
\text { adopters. }\end{array}$ & $\begin{array}{l}\text { Producing } \\
\text { models of the } \\
\text { normative } \\
\text { framework for } \\
\text { action research } \\
\text { studies; } \\
\text { publishing the } \\
\text { findings. }\end{array}$ & $\begin{array}{l}\text { Producing and } \\
\text { distributing a } \\
\text { normative framework } \\
\text { for classroom and } \\
\text { industry use; } \\
\text { instructional guide } \\
\text { and learning } \\
\text { materials. }\end{array}$ & $\begin{array}{l}\text { Evaluating if the } \\
\text { framework } \\
\text { increased } \\
\text { understanding } \\
\text { and reduced } \\
\text { innovation } \\
\text { process } \\
\text { uncertainty. }\end{array}$ \\
\hline
\end{tabular}

Figure 3 Adaptation of E. Rogers Innovation development process for this normative framework

Source: Rogers Everet M. (1995), Difusion of innovations, New York

When shaping an approach to the management of a start-up project, it is important to take into account internal and external factors of the company, i.e. an analysis of competitors and stakeholders should be carried out regardless of the type of methodology. The innovation project management model contains many features of agile but also linear 
methodologies, however, applied in different stages of the project life cycle. As already mentioned in the case of start-ups financed from the public sector, it is important to plan the schedule and budget on a linear basis, as it is necessary to ensure payment deadlines in a given organizational unit. The model created is only a concept and can be verified in further research.

The work on an innovative project is characteristic, but it can use existing elements of project management methodologies, both linear and agile. The process which is an innovative project should also include control methods to verify possible changes and decide whether they are beneficial. The best way to continuously verify is to use the SCRUM methodology, which has short sprints in the tools, so you can easily reach the real problems. One of the techniques that can be used is short-term planning in agile methodologies, but for a project to work it is also necessary to develop a schedule that has its direct origins in linear methodologies. Below is table number 1 presenting proposed documents and tools in particular phases of a start-up project.

Table 1. Documents and tools needed in the various phases of a start-up project

\begin{tabular}{|l|l|}
\hline \multicolumn{1}{|c|}{ Phase name } & \multicolumn{1}{c|}{ Documents/tools } \\
\hline Canva idea & - Business Model Canvas, \\
& - Idea Box Google, \\
& - Market survey. \\
\hline Clarification and implementation & - Kanban table \\
& - Thought map, \\
& - Work shedulde, \\
& - Product specification, \\
& - Document securing intellectualy property, \\
& - Document with a description appriopriate to the \\
& - Selected funding, \\
\hline Finalisation & - Focument with failures and successes of the project. \\
& - Sally product specification, \\
\hline
\end{tabular}

Source: own study.

Documents presented in the table 1 should also be included in the individual phases. They are to make the work easier and faster. In the first phase it is worth to use the Business Model Canvas tool and Google Drive, in which ideas and solutions will be written. The next stage is a good time to use the kanban table/thought map, simple work schedule and description of failures and successes. The last phase should include, first of all, the final specification of the product and the developed sales model. From the linear approach it is worth to use the structured documentation and already developed action plans. Agile approach should be the main template for activities related to the innovative project due to variability and high risk.

In the case of a start-up, the most important thing is not that the project goes according to the planned phases, but that it develops a product/service that the customer wants to buy. The use of project methodologies facilitates the implementation of appropriate tools and techniques in a start-up. 
The main problem during the research was access to information, nowadays there is a significant part of literature on project management on the market, but it focuses on the same issues. There is a lack of issues in the literature concerning the possibility of modifying a given concept. Additionally, start-up is a quite young concept and not defined in the literature, thus the explanation of the concept is quite complicated, also because every specialist or scientist understands start-up and its activities in different ways. The literature should contain more items on the contemporary start-up scene, so that the management model can be defined more. The second important problem is the creation of new value, because in the case of start-ups and their management there are large discrepancies in the concepts, moreover, it is not defined as a separate legal activity and there is no strictly defined framework for the transition to a process-oriented company.

The article focuses on the presentation a proposal for a start-up management system using project management methodologies. This topic is nowadays one of the most important because many start-ups are created and project management strengthens its position as a scientific field. In the future it is worth to develop this topic of work by carrying out research that goes in the direction of development to combine agile and linear approaches. The integration of both approaches and the refinement of the model and its adaptation to innovative ventures will be possible in case the research will also be conducted on start-ups in relation to their effectiveness. Due to the fact that there are a large number of emerging start-ups, testing the failure factors would be the most appropriate course of action.

\section{REFERENCES}

Arundale, K. (2007). Raising Venture Capital Financing in Europe. London: Kogan Page.

Balcerowicz-Szkutnik, M., Sroka, A. (2020). Wspótczesne problemy ekonomiczno-społeczne, metody $i$ modele $w$ rozwoju regionów. Katowice: Wyd. Uniwersytet Ekonomiczny w Katowicach.

Baron, R. A., Henry, R. A. (2011). Entreprensurship: the Genesis of organisations. Washington: American Psychological Association.

Beausoleil, A. (2018), Revisiting_Rogers_the_diffusion_of_his_innovation. Toronto, Rotman School of Management, Nr 6/4.

Berkun, S. (2006) Sztuka zarzadzania projektami. Warszawa: Onepress.

Blank, S. (2010). What's A Startup? First Principles. Gliwice: Helion.

- (2013). Podręcznik Start-upu. Gliwice: Helion.

Brzeziński, N. (2009) Organizacja kreatywna. Warszawa: Wydawnictwo Naukowe PWN.

Bukowski, M., Szpor, A., Śniegocki, A. (2012). Potencjat i bariery polskiej innowacyjności. Warszawa: IBS.

Clarke, L. (1997). Zarzadzanie zmianą. Warszawa: Gebethner\&Ska.

Cheng, C., Lai, M., Wu, W., (2008). Exploring the impact of innovation strategy on $R \& D$ employees job satisfaction: a mathematical model and empirical research, $\mathrm{Nr} 30$.

Chmielarz, W. (2012). Kryteria wyboru metod zarzadzania projektami informatycznymi. “Problemy Zarzadzania”, Nr 38/3.

Floridi, L. (2005). Is semantic information meaningful data?."Philosophy and Phenomenological Research" No. 70/2.

Hua, S., Wemmerlov, U., (2006). Product change intensity, product advantage, and market performance: an empirical investigation of the PC industry. "Journal of Product Innovation Management", No. 23. 
Kałowski, A., Wysocki, J. (2017). Start-up, a uwarunkowania sukcesu. Warszawa: Wydawnictwo Szkoły Głównej Handlowej w Warszawie.

Kopczyński, T. (2014). Rola $i$ kompetencje kierownika projektu $w$ zwinnym zarzązaniu projektami na tle tradycyjnego podejścia do zarządzania projektami. "Studia Oeconomica Posnaniensia”, Nr 270/9.

Kubera, G. (2016). Stwórz jednorożca. Gliwice: One Press.

Maduss, B. J. (2006). Handbuch Projekt management. Stuttgart: Schaffer - poeschelVerlage.

Małyszek, E. (2018). Zarzadzanie projektami w mikro i matych przedsiębiorstwach [Access: 22.11.2020 r.].

Orbik, Z. (2017). Test analysis of the concept of innovation. "Zeszyty Naukowe Politechniki Śląskiej”, Nr 105/1980.

Hillemane, M., Satyanarayana, B. S., Chandrashekar, D. (2019). Technology business incubation for start-up generation: A literature review toward a conceptual framework. "International Journal of Entrepreneurial Behavior \& Research", $\mathrm{Nr} 7$.

Pawlak, M. (2006). Zarzadzanie projektami. Warszawa: Wydawnictwo Naukowe PWN.

Sońta-Drączkowska, E. (2018). Zarządzanie projektami we wdrażaniu innowacji. Warszawa: PWE.

Stemplewska-Żakowicz, K. (2010). Roczniki psychologiczne. Lublin: Wydawnictwo Towarzystwa Naukowego KUL \& Katolickiego Uniwersytetu Lubelskiego Jana Pawła II.

Szmigiel, K., Strojny, J. (2015). Analiza porównawcza podejść w zakresie zarzadzania projektami. Rzeszów: Oficyna Wydawnicza Politechniki Rzeszowskiej im. Ignacego Łukasiewicza.

Wijmans, H. (2001). Creating New Products. New Yersey: Prentice Hall.

Wirkus, M. (2014). Zarzadzanie projektem. Warszawa: PWE.

Wirkus, M., Zejer, P. (2017). Uwarunkowania zastosowania metodyk zwinnych w przedsiębiorstwie. Gdańsk: Wydawnictwo Politechniki Gdańskiej.

Wziątek-Kubiak, A. (2011). Zarzadzanie innowacjami a konkurencyjność. Dąbrowa Górnicza: Wyższa Szkoła Biznesu w Dąbrowie Górniczej.

Project management Institute (2008). A Guide to the Project Management Body of Knowledge. NewtonSquare.

Start-up Latin America 2016: building an innovative future (2016). Paris: OECD [Access: 22.11.2020].

www.system-kanban.pl [Access: 17.10.2020].

DOI: 10.7862/rz.2021.hss.17

The text was submitted to the editorial office: December 2020.

The text was accepted for publication: June 2021. 
